\title{
"I am being taught my own work": Editor Claire Pratt of McClelland and Stewart
}

\author{
Ruth Panofsky*
}

One of the first women to enter the book trade as a professional editor, Claire Pratt (I92I-I995) was at the vanguard of mid-twentieth century Canadian publishing. At McClelland and Stewart, where she was senior editor from 1956 to 1965 , Pratt made her most significant contribution to Canadian literary culture. She worked collegially with Jack McClelland, the charismatic head of the firm, and experienced firsthand the challenges and rewards of Canadian literary publishing. She also worked closely with English professor Malcolm Ross, who served as general editor of the firm's paperback reprint series New Canadian Library, and directly with some of Canada's most prominent writers, including parliamentarian Stanley Knowles, journalist Peter C. Newman, historian W.L. Morton, novelists Henry Kreisel and Margaret Laurence, and poet Irving Layton. Unlike the majority of women in publishing "whose domestic and behind-the-scenes labour [as wives, daughters, and employees often] made the family business possible, or made it flourish," and who typically toiled invisibly in a field dominated by men, Pratt's interest in literature and art was fostered by both her parents who encouraged her to pursue a career in publishing.

This essay focuses on the nine-year period when Claire Pratt was a key member of McClelland and Stewart's editorial staff. It

* Ruth Panofsky is Professor of English at Ryerson University in Toronto. Her latest book, The Literary Legacy of the Macmillan Company of Canada: Making Books and Mapping Culture, was published by the University of Toronto Press in 20I2. Her research on Claire Pratt is part of a larger project on women in English-language book publishing in Canada, 1900-2000. Acknowledgements are due to SSHRC for its support of this research, to Evan Maura and Jessica Whitehead, who provided invaluable research assistance in the writing of this essay, and to the anonymous peer reviewers, who offered insightful comments toward revision. A version of this essay was presented at the 2012 annual meeting of the Bibliographical Society of Canada at the University of Waterloo.

I Leslie Howsam, "In My View: Women and Book History," SHARP News 7 , no. 4 (Autumn I998): I-2 (2). 
situates Pratt's cultural work as editor within the larger conceptual frame of book history studies. My approach heeds Robert Darnton's injunction to "tap the papers of publishers . . . the richest of all sources for the history of books" and affirms his view of the "key role of publishers" in shaping literary culture. I also aim to follow Carole Gerson's exemplary research into women and print culture. In Canadian Women in Print 1750-19I8 (Waterloo: Wilfrid Laurier University Press, 20Io), Gerson underscores the need to mine archival repositories - in this case, the Mildred Claire Pratt (MCP) fonds, housed in the E.J. Pratt Library at Victoria University in Toronto, Ontario, and the McClelland and Stewart (M\&S) fonds housed in the William Ready Division of Archives and Research Collections at McMaster University in Hamilton, Ontario - to unearth and interpret women's foundational work in the book trade. The archival record provides ample evidence of one woman's active and sustained agency "in the material production of literary culture." 3 Finally, Leslie Howsam's understanding of book history as "a male domain" that has been gendered "masculine" 4 informs this reading of Pratt's seminal contributions to Canadian publishing. This essay responds to Howsam's call to attend to the women who have laboured in publishing and have made it a flourishing industry. By foregrounding and analyzing Claire Pratt's important influence as a cultural worker - by "restoring to visibility" her editorial efforts in Canadian publishing - I seek, in a preliminary way, to redress the ease with which "women's contributions to print culture [have] fade[d] from view" and the wider understanding of publishing practice.

Born in Toronto in 192I, Mildred Claire Pratt was the only child of renowned poet E.J. (Edwin John) Pratt and magazine editor Viola Whitney Pratt. Raised in a vibrant literary household, Pratt was adored by her mother, the esteemed editor of World Friends, a magazine for youth published under the auspices of the Women's

2 Robert Darnton, "What Is the History of Books?" Daedalus III, no. 3 (Summer I982): 65-85 (76).

3 Simone Murray, Mixed Media: Feminist Presses and Publishing Politics (London: Pluto Press, 2004), 23.

4 Howsam, "In My View," I.

5 Trysh Travis, "The Women in Print Movement: History and Implications," Book History II (2008): 275-300. (292); Elizabeth Long, foreword to Women in Print: Essays on the Print Culture of American Women from the Nineteenth and Twentieth Centuries, ed. James P. Danky and Wayne A. Wiegand (Madison: University of Wisconsin Press, 2006), xv-xxi (xx). 
Missionary Society of the United Church of Canada, ${ }^{6}$ and her father, a professor of English at Victoria University who thrice won the Governor General's Literary Award for poetry. Until illness beset her in 1925, her father, an avid golfer, had hoped to transfer his love of the sport to his daughter. Tragically, at the age of four Pratt contracted polio and it was the determining factor in her life. It led to infection, countless surgeries, and protracted periods of recuperation, which resulted in the need for home schooling by her mother. As she recounted in 1968 :

I had numerous operations; in fact, I don't know how many. They seemed to be going on all during my childhood. Much of the time my leg was in a brace, and when not in a brace it was in a cast. The worst of it was the osteo infection that went right through my body. It was this that really caused all the trouble in my life. The actual polio was over and done with by the time I was fifteen, but the infection meant that I had to have extensive scrapings of the bone, and operations that did a great deal of damage to me as a person. ${ }^{7}$

The operations left Pratt with a truncated pelvis and chronic pain resulting from osteomyelitis, but repeated physical trauma also gave rise to resilience and determination, qualities that sustained her throughout her life.

Pratt was educated at the University of Toronto, where she was awarded a gold medal in philosophy, and Columbia University, where she completed a graduate degree in international studies. She was a self-described artist and book editor ${ }^{8}$ who worked continually, despite consistent pain, to refine her professional practice. In Toronto, she was taught by painters Fred Varley, A.J. Casson, and Carl Schaefer, studied portrait painting at Northern Vocational School, and took sketching trips. She attended the Doon Summer School of Fine Arts (now the Homer Watson House and Gallery) in Kitchener, Ontario, and later took courses through the print department of the School of the Museum of Fine Arts, Boston.

Pratt was a versatile artist, known primarily for her powerful woodcuts, wood engravings, and lithographs. By the early I950s, she

\footnotetext{
6 Robert C. Brandeis, "Claire Pratt: Art and Adversity," DA: A Journal of the Printing Arts 46 (Spring-Summer 2000): 3-28 (5, 7).

7 Quoted in David G. Pitt, E.J. Pratt: The Master Years 1927-I964 (Toronto: University of Toronto Press, 1987), 73.

8 Brandeis, "Claire Pratt," II.
} 
had made the woodcut "her primary form" and between 1954 and I975 she exhibited work throughout Canada, the United States, and Europe. Her woodcuts appeared in juried shows at the Art Gallery of Hamilton, the London Regional Art Gallery, the Montreal Museum of Fine Arts, and travelling exhibits throughout Ontario and the Maritime provinces. She exhibited early work at the Museum of Fine Arts in Boston, and the Old Bergen Art Guild in New Jersey mounted a solo show that featured thirty-one of Pratt's prints in colour and black and white. Her woodcuts were also represented in shows in Florence, Paris, and Luxembourg. Pratt's interest in Japanese art informed her poetic practice. She embraced haiku as a natural complement to her intricate graphic images and regularly melded the two art forms by illustrating her own verse. In 1965, she published Haiku, the first book of haiku to be issued in Canada. ${ }^{\text {IO }}$

Pratt's expansive abilities and interests included family history. In 1971, McClelland and Stewart published The Silent Ancestors: The Forebears of E.J. Pratt, the result of Pratt's extensive research into her paternal genealogy. Nearly two decades later, she honoured her mother by editing and publishing Viola Whitney Pratt: Papers and Speeches (Toronto: Lugus Productions, 1990) and Viola Whitney Pratt: A Testament of Love (Toronto: Lugus Productions, 1990). Her mother's archives were the source of both volumes, the first a record of Viola Pratt's work in the public domain, the second a mother's private diary that centres on her beloved daughter.

Pratt's apprenticeship in the book trade was both entrepreneurial and editorial. In 1945, she and her business partner Olive Smith established the Claire Pratt Book Service, "a specialized book shipping and addressing service." "I She closed the purchasing agency in 1949 and undertook freelance editorial work for the Macmillan Company of Canada, Ryerson Press, and the University of Toronto Press. In 1952, she became an editor with Harvard University Press and relocated to Boston, but illness and the need for further surgery forced her to leave the position in 1954.

When Pratt joined McClelland and Stewart in 1956 Canadian publishing was enjoying a period of intensive growth and new Canadian writers were achieving unprecedented success. She was

9 Brandeis, "Claire Pratt," I5.

Io Brandeis, "Claire Pratt," 25. See Claire Pratt, Haiku (Toronto: [privately published], I965); published as Haiku (Toronto: Haiku Society of Canada, 1973).

II Brandeis, "Claire Pratt," I3. 
not the company's first female editor. Pratt was preceded by Sybil Hutchinson, who served as editor-in-chief from 1946 to 1950, but Hutchinson never had a rapport with Jack McClelland. Pratt, on the other hand, demonstrated both editorial skill and a capacity to foster productive relationships with colleagues, most notably the unpredictable McClelland, and authors known to be similarly willful and demanding, such as Peter C. Newman and Irving Layton. It was at McClelland and Stewart that Pratt's intelligence, professionalism, and appealing personality were most on view. Moreover, the deep satisfaction she derived from her professional associations helped sustain her during recurring bouts of physical pain that finally forced her early retirement from the unforgiving rigour of the publishing life.

In light of the physical strain she had to endure, Pratt was remarkable for her wide-ranging abilities and the degree of her accomplishment and ambition. She took on major responsibilities, which coincided with an era of publishing activity at McClelland and Stewart new to the annals of Canadian houses. She attended press conferences and editorial meetings, negotiated with other publishing companies - Oxford University Press Canada and Clarke, Irwin, for example - evaluated countless submissions, edited manuscripts and ushered them through the publication process, prepared indexes, proofread galleys, and met and corresponded regularly with authors. For Pratt, editorial work was a hectic round of activity, akin to "labouring in a whirlwind." 22 Periodically, she travelled out of town to meet with authors who did not reside in Toronto; regularly, she devoted evenings and weekends to editorial projects; and often, she "worked like a devil"'3 to meet publishing deadlines.

Jack McClelland, who had a keen appreciation for professional competence, soon came to rely on Pratt for her expertise and dedication. Although McClelland's demands frequently threw Pratt's "day into confusion" and led to general "uproar,"I4 publisher and editor formed a close connection. Pratt withstood McClelland's "rampage[s],"I5 attended meetings or met with authors in his stead, and often took over his various projects. In April 1958, for example,

I2 Mildred Claire Pratt, ed., Viola Whitney Pratt: A Testament of Love (Toronto: Lugus Productions, 1990), 52.

I3 Claire Pratt diary, I6 February 196I, Mildred Claire Pratt, Fonds 22, box 17, file I, Special Collections, E. J. Pratt Library, Victoria University (hereafter MCP Fonds).

I4 Claire Pratt diary, 9 April 1959, MCP Fonds, box 17, file I.

Is Claire Pratt diary, I6 February I96I, MCP Fonds, box I7, file I. 
as she was looking forward to a much-needed vacation, McClelland warned her - only half in jest - that her "desk would be piled high with work on my return so that any good my holiday would do me would be undone." ${ }^{16}$ In fact, Pratt was inundated with work, at times feeling so much tension at the office that she wondered whether she and her colleagues would get through the day without suffering "a nervous breakdown." 77 That she would not succumb easily to anxiety is evident in her rejection of an offer from author Farley Mowat who visited his publisher's East York office at 25 Hollinger Road "with a bottle of rum, foisting a glass to me most of which I poured out the window, not wanting to lose my job." ${ }^{\text {"8 }}$ Clearly, Pratt thrived in the intense, somewhat chaotic atmosphere of Hollinger House and was satisfied in her position. It was "hard work" but "happy times."'9

A source of particular pleasure was Pratt's work on the New Canadian Library (NCL), McClelland and Stewart's landmark reprint series and the first major paperback series in Canada to mark the arrival of the I950s post-war paperback revolution. Launched on 17 January 1958, the success of the NCL has been profound and it continues today as the premier Canadian paperback series. Pratt was designated in-house editor for NCL and she welcomed the opportunity to launch a series of books tied closely to her knowledge of and affinity for Canadian literature. Working alongside Jack McClelland and Malcolm Ross, Pratt was instrumental in developing and expanding the paperback series, securing publishing rights, communicating with authors and editors, and shepherding titles through the press. As NCL historian Janet Friskney affirms, "in-house editors such as Claire Pratt ... demand much more recognition for their editorial influence in the production of certain pre-1900 titles."

Since the nature of Pratt's work on key NCL titles is described in full in Friskney's 2007 study of the New Canadian Library, I offer here a summary of her editorial mediacy. Although general editor Malcolm Ross was responsible for securing a critical introduction to each NCL volume, Pratt oversaw most in-house matters pertaining to the series. Often, she was asked to "select and proofread the source

Claire Pratt diary, 5 April I958, MCP Fonds, box I7, file I.

Claire Pratt diary, I7 March 1960, MCP Fonds, box I7, file I.

Claire Pratt diary, I9 June 1961, MCP Fonds, box I7, file I.

Pratt, ed., Viola Whitney Pratt: A Testament of Love, 49.

20 Janet B. Friskney, New Canadian Library: The Ross-McClelland Years, 1952-1978

(Toronto: University of Toronto Press, 2007), I50. 
texts on which NCL reprints were based," ${ }^{21}$ a choice that required significant knowledge of a work's bibliographical provenance and publication history. At times, her view of a potential title was solicited. In 1962, for example, she enthusiastically endorsed inclusion of James De Mille's A Strange Manuscript Found in a Copper Cylinder (first published in I888); the NCL edition finally appeared in 1969, four years after Pratt had resigned from McClelland and Stewart.

Pratt worked closely with Robert McDougall on his $1958 \mathrm{NCL}$ edition of Thomas Chandler Haliburton's The Clockmaker or, The Sayings and Doings of Samuel Slick, of Slickville (First Series) (first serialized in 1835-36) to ensure stylistic consistency in a text that adopted a Yankee idiom. She effected a near feat of magic when she managed to expand W.H. Drummond's Habitant Poems to IIo pages. When editor Arthur J. Phelps stubbornly refused to include more than twenty-two of Drummond's judiciously selected and most memorable poems, Pratt devised to spread out the verse and pad the slender 1960 NCL edition with indexes. She and Carl Klinck established a clear editorial policy in an attempt to align their joint efforts to produce an edition of Frances Brooke's The History of Emily Montague that would retain the flavour of the original 1769 edition. The copyright page of the 196I NCL edition makes note of the editorial changes made to the copy-text. Pratt took similar care with Klinck's I962 NCL edition of Susanna Moodie's Roughing It in the Bush (first serialized in 1847), the first abridged title to appear in the series.

Pratt was instrumental in bringing Thomas McCulloch's Letters of Mephibosheth Stepsure (first serialized in I82I-23) to the New Canadian Library. She served as conduit between Malcolm Ross and literary critic Northrop Frye, librarian Douglas Lochhead, and philosopher John Irving, the three scholars associated with the project. First, she went to great lengths to secure a reading copy of the rare book. She approached Douglas Lochhead, librarian of Dalhousie University, who encouraged her interest in McCulloch's work and willingly lent her his library's only copy of the Letters. Second, to increase the work's market potential, she endorsed the use of The Stepsure Letters as an abbreviated title. Third, when Lochhead's research uncovered six previously uncollected letters, she was called upon to make a selection of new material for inclusion in the 1960 NCL edition. Pratt's editorial intervention was further necessary at the proof stage. Another editor had mistakenly modernized McCulloch's spelling and

21 Friskney, New Canadian Library, I50. 
Pratt - who sought "to perpetuate rare and worthwhile Canadian works" 22 and believed it was "important to adhere to the source"23 of such a core work - delayed publication and corrected the proofs to accord with the copy-text.

Pratt's principal, Jack McClelland, had not the inclination, sufficient personnel, or the financial resources to underwrite scholarly editions of nineteenth-century Canadian works - such editions did appear in the I980s and I990s through Carleton University's Centre for Editing Early Canadian Texts. Nonetheless, the New Canadian Library was instrumental in generating an audience for these longoverlooked but significant texts. Moreover, despite early mixed reviews and inadequate profits, the NCL prevailed. Today, under the aegis of Random House of Canada, it remains a prestige imprint on paperback editions of Canadian works.

Pratt deserves further recognition for her editorial labour on a number of post-1900 NCL titles. She brought her keen editorial eye to Sinclair Ross's As For Me and My House (first published in 194I). As Friskney details, Pratt's few suggestions toward minor revision were made in the interest of clarity - changes to prepositions and conjunctions, for example - and were accepted by Ross for the 1958 NCL edition. Pratt also worked closely with Edward Meade, who was grateful for the opportunity to undertake extensive revision to Remember $\mathrm{Me}$ (first published in 1946) in preparation for its 1965 publication in the New Canadian Library. Novelists A.M. Klein and Brian Moore were thanked personally by Pratt for the opportunity to issue The Second Scroll (first published in 195I) - an "exceptionally fine book with its fine nobility of language" 24 - and The Lonely Passion of Judith Hearne (first published in 1955) - in the New Canadian Library in 196I and 1964, respectively. An especially attentive editor, Pratt regularly took the time to convey her appreciation for an author's work. That same regard led her to exclude extraneous matter that could detract from a text. Hence, she omitted the original introduction to Hugh MacLennan's novel Each Man's Son (first published in 195I;

22 Claire Pratt to Douglas Lochhead, 8 January 1960, McClelland and Stewart Fonds, series Cae, box I2, file 26, William Ready Division of Archives and Research Collections, McMaster University Library (hereafter M\&S Fonds).

23 Claire Pratt to Malcolm Ross, I4 September 1960, M\&S Fonds, series Cae, box I2, file 26.

24 Claire Pratt to A. M. Klein, I5 May 196I, M\&S Fonds, series Cae, box I2, file I. 
NCL in 1962) and the original illustrations in Paul Hiebert's Sarah Binks (first published in 1947; NCL in 1965).

Beyond the New Canadian Library, Pratt's editorial responsibilities at McClelland and Stewart included important trade titles by notable figures in Canadian politics and culture. She worked tirelessly, for example, with parliamentarian Stanley Knowles on his book, The New Party (196I). When Jack McClelland invited Knowles to write a book on the emerging New Democratic Party, he did not foresee the arrival of a weighty manuscript in need of serious editorial intervention - a task he entrusted to Pratt. McClelland believed Knowles's effort could "become a fairly good book," but only after extensive editing. He urged Pratt to "be quite ruthless about the revision. The repetition is overbearing particularly in the middle chapters! I think it must be eliminated and you will have to do so with extreme care." ${ }^{25}$

McClelland knew that Pratt could be "ruthless" ${ }^{26}$ in her editing without sacrificing the good grace of the author, a delicate balancing act that would elude a less skilful and humane editor. Pratt's literary upbringing and love for her poet father gave her particular insight into the writerly personality and the profound connection between a writer and his work. She was not an imperious editor; rather, she respected the individual's claim to his or her work and sought to ensure the publication of a writer's best effort. Pratt was especially sensitive in her communication with authors and certain to show appreciation. After she had worked painstakingly on his manuscript, she wrote to Knowles affirming that she had "never seen such a beautifully prepared script" and hoped that he would not be offended by her "recommendations for cutting." Moreover, if he felt "that any vital points have been omitted or your meaning distorted in any way," Pratt would defer to the author's expertise. In fact, Knowles rejected many of Pratt's suggestions and she was required to undertake further and intensive line editing prior to publication; she also prepared the index to Knowles's book. That Knowles acknowledged her "tremendous job of editing" 27 and McClelland reported that "Knowles seemed pleased with your work. Good show" ${ }^{28}$ attests to Pratt's editorial

25 Jack McClelland to Claire Pratt, [January 196I], M\&S Fonds, series Cae, box I2, file 5 .

26 Jack McClelland to Claire Pratt, [January 196I], M\&S Fonds, series Cae, box I2, file 5 .

27 Claire Pratt to Stanley Knowles, 24 January 196I, M\&S Fonds, series Cae, box I2, file 5 .

28 Jack McClelland to Claire Pratt, [196I], M\&S Fonds, series Cae, box I2, file 5 . 
finesse and her ability to work with an author whose attention to detail is recorded in their correspondence.

Pratt also worked closely and expeditiously with journalist Peter C. Newman on his book Renegade in Power: The Diefenbaker Years (1963). Undaunted by Newman's reputation - he was known as a demanding and uncompromising author - Pratt brought her usual clarity and calm to their editorial exchanges. To ensure publication in October 1963, Pratt was required to focus all her time and attention on Newman's manuscript. The author received a list of editorial changes made to his manuscript and was permitted to make alterations at the galley stage. Although she felt pressed for time and worked diligently to meet the publication deadline, Pratt retained her equilibrium throughout the editorial process. She lauded Newman's book as "a remarkable accomplishment. It has been great fun to work through." 29 When she received Newman's extensive list of emendations, Pratt remained diplomatic: "What a lot of corrections there are, to be sure. This is going to involve a great deal of re-setting but better now than in pages." ${ }^{30}$ While she incorporated the majority of Newman's changes, she also sought to minimize the cost of re-typesetting by ignoring several of his corrections. Newman praised Pratt's "excellent editing,"3I but was disappointed "that some of the changes I made on the galleys have not been made on the page proofs"; in the end, his final revisions were "done in a way that will require the least amount of resetting and $\mathrm{NO}$ changes in pages ... But I really must insist that the changes that I've marked are made." ${ }^{32}$

Pratt's capacity to forge productive relationships with authors was especially evident in the case of Newman. Notwithstanding the pressure she had endured to meet the publication deadline, she worried that mistakes had crept into Newman's book - "I shouldn't be surprised if there were the odd one, considering the speed with which the book was rushed through." Her careful work on Newman's

29 Claire Pratt to Peter Newman, is August 1963, M\&S Fonds, series Cae, box I2, file 60.

30 Claire Pratt to Peter Newman, 27 August 1963, M\&S Fonds, series Cae, box I2, file 60.

31 Peter Newman to Claire Pratt, I8 August 1963, M\&S Fonds, series Cae, box I2, file 60.

32 Peter Newman to Claire Pratt, i5 September 1963, M\&S Fonds, series Cae, box I2, file 60. 
"lively and informative" 33 volume won her the gratitude of the author, however. Newman appreciated "the speed and skill with which my manuscript was handled" - so much so, in fact, that he promised to send Pratt a list of corrections, just "[i]n case there is a second edition." ${ }^{34}$ Despite her affable nature, Pratt no doubt felt great relief following the publication of Renegade in Power - which sold wildly and set a new precedent for the critical examination of Canada's political leaders. Happily, she sent Newman his author's copies, returned his "seventeen-pound manuscript,"35 and turned her attention to other editorial projects.

With historian W.L. Morton, Pratt was equally solicitous. Morton was executive editor of the Canadian Centenary Series, an eighteenvolume history of Canada and one of McClelland and Stewart's first attempts to issue prestige academic publications. In November 1963, Morton was struggling to pare down The Critical Years: The Union of British North America, I857-1873 (1964), one of the books in the series. Pratt apologized for having "distressed you so much over the word cutting" ${ }^{36}$ and eased the author's anxiety by granting him more time for revision. Morton valued Pratt's understanding and forgave her delayed response to his completed manuscript when she explained that she had "been slower than I anticipated ... owing to a number of factors, both personal and editorial. You, on the other hand, have attended to the manuscript with great dispatch, and this I appreciate." ${ }^{37}$ Ever gracious and accommodating, Pratt won the respect and goodwill of authors who shared her genuine enthusiasm for the literary enterprise.

Pratt took deepest pleasure in her work with contemporary writers of fiction and verse. She wrote appreciatively to Henry Kreisel, whose novel The Betrayal was issued by McClelland and Stewart in 1964. Kreisel's revisions to the close of his novel met with Pratt's approval: she found his resolution - the use of two postscripts - appropriate and

33 Claire Pratt to Peter Newman, i9 October 1963, M\&S Fonds, series Cae, box I2, file 60.

34 Peter Newman to Claire Pratt, 20 October 1963, M\&S Fonds, series Cae, box I2, file 60.

35 Claire Pratt to Peter Newman, i9 October 1963, M\&S Fonds, series Cae, box I2, file 54 .

36 Claire Pratt to W.L. Morton, 20 November 1963, M\&S Fonds, series Cae, box I2, file 55 .

37 Claire Pratt to W.L. Morton, 9 March 1964, M\&S Fonds, series Cae, box I2, file 55 . 
meaningful, and was gratified to have such "a deeply moving book, with great significance"38 on her fall list. Kreisel was buoyed by Pratt's words and thankful for her assiduous treatment of his manuscript.

One of Pratt's most important relationships was with fiction writer Margaret Laurence. Pratt cherished her association with Laurence and recalled with great affection "the day the manuscript for This Side Jordan arrived on my desk. Shortly afterwards I had lunch with Margaret Laurence and was enchanted with the warmth of her personality. She was on the eve of leaving for England and was kind enough to invite my mother and me to visit her. This we were fortunate enough to do twice, in 1964 and 1967, at Elm Cottage,"39 Laurence's beloved home in the village of Penn in Buckinghamshire from 1962 to 1973. This Side Jordan (1960) initiated an abiding connection between Laurence and Pratt, and established McClelland and Stewart as Laurence's Canadian publisher. Author and editor shared a compassionate sensibility that drew one to the other. Laurence was moved by Pratt's commendation of her prose, and Pratt was grateful for the opportunity to work closely with an author she admired both personally and professionally.

This Side Jordan was followed by The Tomorrow-Tamer (1963), Laurence's collection of short stories set in Africa. Pratt's assessment of the volume, incisive and effusive in its praise, bears reproduction here:

[The stories] are superbly done ... beautifully written, in a style that captures the feeling of Africa in all its turmoil, conflict, and naked pathos. The fragmentary and futile attempts at understanding between black heart and white are described with compassion and insight. Also the rift within Africa itself hopelessly touched with the white man's civilization.

Characterizations are excellent. "The Merchant of Heaven" is a typically unimaginative type characteristic of evangelistic zeal caught up in the mysteries of Revelation. In "The Perfume Sea" two people, lost souls finding romance in a harmless deception concerning the emptiness of their past. "The Rain Child" - African brought up in England (country of rain) unable to adjust to Africa, her supposed home.

38 Claire Pratt to Henry Kreisel, 9 April 1964, M\&S Fonds, series Cae, box I2, file 6.

39 Mildred Claire Pratt, ed., Viola Whitney Pratt: Papers and Speeches (Toronto: Lugus Productions 1990), I63. 
These stories are powerful, unique, exquisite. I recommend them unreservedly for publication by us. And my guess is that they would sell. ${ }^{\circ}$

Pratt intuited Laurence's lack of confidence in her early work and was willing to share this positive view of her stories. In her characteristically open way, she was pleased to offer a glowing report and wrote immediately to Laurence: "One of the best things that has happened to me in a long time is your manuscript of short stories. I wish there were some way in which I could put across to you how really enthusiastic I feel about them, Margaret. Depth of compassion and insight, combined with stylistic beauty and the use of the word or phrase that is exactly right, make of each of them a pure gem, a true union of the artist and the craftsman. In short they are marvellous." ${ }^{\mathrm{I}}$

Boosted by such unqualified praise, Laurence sent Pratt the manuscript of a novel she had been writing for some time, her first to adopt a Canadian setting. "Hagar," as The Stone Angel (1964) was provisionally titled, elicited a more measured response from Pratt, but one that recognized the work's probing power: "The book is beautifully written, with sensitivity and compassion. In spite of the drabness, the hopelessness of the theme, it is not depressing, at least I do not find it so. In its spotlighting of a condition endemic in our way of life, the book does not present anything new in our literature but does, however, present it in a flawless way. I find it difficult to know how well it would sell here." ${ }^{22}$ Pratt's assessment of Laurence's artistry was accurate. What she did not anticipate was the triumph of the novel and its lasting impact on Laurence's career. The publication of The Stone Angel, the first in what became a series of novels set in the fictional town of Manawaka, heralded a new phase in Laurence's productivity and announced the emergence of a new Canadian writer with a distinctive voice and an unmistakable appreciation for her country and its people. Pratt was, however, the first Canadian editor to discern the nuances of Laurence's writerly voice and vision, and she remained a touchstone figure in the author's life.

40 Claire Pratt, reader's report, I8 February 1963, M\&S Fonds, series Cae, box I2, file 7 .

4I Claire Pratt to Margaret Laurence, 20 February 1963, M\&S Fonds, series Cae, box I2, file 7 .

42 Claire Pratt to Jack McClelland, 25 July 1963, M\&S Fonds, series Cae, box I2, file 7 . 
More than any other writer, poet Irving Layton brought out Pratt's vivaciousness. A Red Carpet for the Sun (1959) was the first collection of Layton's verse edited by Pratt, and the connection between poet and editor was given an auspicious start when the book received the Governor General's Literary Award for poetry in 1959. The foundation for a mutually satisfying relationship - characterized by respect, trust, and genial humour - and the pattern of exchange between poet and editor were laid through their initial joint effort to produce this landmark volume, a selection of Layton's verse written between 1942 and 1958 .

Pratt and Layton enjoyed an instant rapport. Early on, Pratt showed a keen understanding of Layton's complex and provocative personality, his profound belief in poetry as salve for the soul, and his desire to love. She penetrated Layton's grand public persona he was renowned for his bravado - and appreciated his private need for approval and human connection. Over the years, Layton sought Pratt's opinion of his poetry. He negotiated constantly: if he were to omit a poem from a collection, might he replace it with another? $\mathrm{He}$ tested Pratt's patience by continually revising a manuscript until the moment it was forwarded to the printers. He also enriched Pratt's professional life and offered some of the most heartfelt expressions of gratitude she received over the course of her career at McClelland and Stewart.

Layton liked to discuss the relative merits of his verse. He sent Pratt a copy of "New Tables" for inclusion in A Red Carpet for the Sun; he did not think it "a bad poem. How do you feel about it?" 43 Pratt's response - "It is a splendid poem and I am delighted that we shall have the chance to include it in the collection" 44 - assuaged Layton's concern - "I'm pleased, very much so, that the poem ... finds favour with you." 45 This was the first of many similar exchanges. Layton regularly sought reassurance that his verse was strong, and Pratt was prepared, when necessary, to bolster the poet's flagging confidence.

Early in 1959, poet and editor met in person for the first time and Layton admitted that the encounter would have been pleasurable

43 Irving Layton to Claire Pratt, [December 1958], M\&S Fonds, series Cae, box I2, file II.

44 Claire Pratt to Irving Layton, I8 December 1958, M\&S Fonds, series Cae, box I2, file II.

45 Irving Layton to Claire Pratt, 26 December I95[8], M\&S Fonds, series Cae, box I2, file II. 
"even under the most distressing of circumstances." ${ }^{46}$ Layton's openness matched Pratt's warm personality and he developed a sense of kinship for his editor. Layton also respected Pratt and relied on her editorial judgment. Although he offered a rough chronological arrangement for the poems in A Red Carpet for the Sun, he deferred to Pratt and invited her to "play around with variations, if you feel that a better pattern would be the result." ${ }^{47} \mathrm{He}$ was "jubilant" when Pratt corrected a serious error in page proofs, the misformatting of many lines of verse. "Bless your dear heart," Layton declared, "I call that splendid, and my spirits are once again skyrocketing to the sky." ${ }^{8}$ When the book was launched later that year, Layton and Pratt had a chance to reconnect in Toronto. Layton savoured being feted, but regretted that he had not had time for a long discussion with his prized editor.

The tie between Pratt and Layton strengthened with each successive project and their correspondence records an increasing frankness, free of rancour. Layton used Pratt as a sounding board for his thoughts on the purpose of poetry. He intended his next book, The Swinging Flesh (196I), a collection of stories and poems, "to have the tonic effect of a brisk thunder-shower. I want it to rip through the heavy smog of fellowly liberalism, togetherness, etc. Nowadays if a book of short stories and poems doesn't make some people mad and others glad, it might just as well be left to moulder in manuscript form." 49 Pratt accepted Layton's desire to "open the door for real living poetry" 50 - the typescript included poems that were overtly vulgar, sexual, and satirical of the bourgeoisie - but she balked at his use of "rod-assed" and his reference to the reader as a dummkopf in his draft foreword to the volume and urged him to consider alternate phrasing. Pratt's affectionate closing, "Yours in Dumkopfheit [sic]," 51 signaled her certainty that Layton would not be irked by her editorial

46 Irving Layton to Claire Pratt, Io March 1959, M\&S Fonds, series Cae, box I2, file II.

47 Irving Layton to Claire Pratt, 26 December I95 [8], M\&S Fonds, series Cae, box I2, file II.

$4^{8}$ Irving Layton to Claire Pratt, ıo March 1959, M\&S Fonds, series Cae, box I2, file ir.

49 Irving Layton to Claire Pratt, 9 January 1960, M\&S Fonds, series Cae, box I2, file 9 .

so [Claire Pratt] to Irving Layton, 9 January 196I, M\&S Fonds, series Cae, box I2, file 9.

5I Claire Pratt to Irving Layton, I2 January 1961, M\&S Fonds, series Cae, box I2, file 9. 
suggestions. The poet relented and omitted both terms from the published foreword.

Layton's persistent practice of forwarding new and replacement poems - each a self-declared "damn fine lyric" 52 - for inclusion in his forthcoming volume may have tried Pratt's patience, but poet and editor only came to an impasse over a single poem, "Why I Don't Make Love to the First Lady," which proclaims in reference to Jacqueline Kennedy, "Of course I could have her! / In a flash, with a snap of my fingers. / An arrogant magician, / I'd put words under her perfect feet / and make her fly to me." ${ }^{53}$ After repeated discussions with Layton, Pratt wrote him a measured letter outlining why the poem ought to be excluded from The Swinging Flesh. She believed the poem was too topical and lacked taste and humour; she wondered "do you really think it's all that good?" 54 Evidently, Layton believed strongly in the poem, for no amount of cajoling from his otherwise influential editor who sought to please him - "all your requests have been taken care of ... thus far with gladness and delight" " dissuade him from including the piece in his collection: "this poem makes the kind of statement I feel ought to be made by poets who are lucky enough to live in countries where the censor doesn't decide what's printable or not. I intend to write many more such poems, only sharper and more bitter." ${ }^{56}$ Layton was "firm and pleasant" 57 and to object further would prove futile, so Pratt conceded defeat.

Layton admired Frank Newfeld's cover design for The Swinging Flesh and expressed muted complaint when he was obliged to await arrival of his author's copies. In truth, he was a privileged author whose book of stories and poems appeared in 196I without the formality of a signed contract, evidence of the bond of trust that had been forged between himself and his publisher. Layton's indebtedness to Pratt for her professional handling of his work and their personal

52 Irving Layton to Claire Pratt, [March 1961], M\&S Fonds, series Cae, box I2, file 9 .

53 Irving Layton, The Swinging Flesh (Toronto: McClelland and Stewart, 196I), I73-74 (I73).

54 Claire Pratt to Irving Layton, 22 February 196I, M\&S Fonds, series Cae, box I2, file 9.

55 Claire Pratt to Irving Layton, I March 1961, M\&S Fonds, series Cae, box I2, file 9.

56 Irving Layton to Claire Pratt, Io March 1961, M\&S Fonds, series Cae, box I2, file 9.

57 Claire Pratt to Jack McClelland, I6 January I964, M\&S Fonds, series Cae, box II, file $2 \mathrm{I}$. 
tie would intensify further over the production of two additional volumes of verse.

Balls for a One-Armed Juggler (1963) was issued with alacrity and minimal fuss. In September 1962, Jack McClelland forwarded Layton's manuscript to Pratt with the injunction that she was to meet an impending publication deadline of January 1963. Quickly, Pratt determined that the volume needed little editorial intervention. In her view, Layton had "arrived at a certain height from which your message is more thoroughly communicated than at any time previously ... You can accept this from one who ... [has] never pretended to like anything of yours or anyone else's that I didn't like." ${ }^{8}$ Not surprisingly, Layton was buoyed by Pratt's "perceptivity and honesty" which corroborated his own feelings of success: "If you were here beside me I'd hug you, I am so elated." ${ }^{9}$ As she awaited the arrival of Layton's trademark foreword - most were written to inflame the reader - Pratt prepared the volume for publication. By 28 January 1963, Layton had received his author's copies and, once again, he expressed gratitude for Frank Newfeld's triumphant design: the front cover adapted a photograph of a bearded and mustachioed Irving Layton. Praise for Pratt came from Layton and McClelland alike who lauded her expeditious handling of the book. By 1963, she was not only a practised editor with great executive ability; she was also highly skilled in managing interpersonal relationships - especially with demanding poets and publishers.

The Laughing Rooster (1964) was the last of Layton's books to be ushered through the press by Pratt. Its production, unlike that of Balls for a One-Armed Juggler, was more typical of Layton and involved the ongoing submission of poems, delayed delivery of a preface, and heated debate over the inclusion of contentious material. Upon submission of each manuscript, Layton anxiously awaited Pratt's response to his latest work and The Laughing Rooster was no exception. He believed he had "written most of the poems with my own blood" and claimed - as was usual - to have assembled a "rich, complex, and many-textured" ${ }^{\circ}$ book. Pratt's endorsement of his most recent

58 Claire Pratt to Irving Layton, [September 1962], M\&S Fonds, series Cae, box I2, file io.

59 Irving Layton to Claire Pratt, 17 September 1962, M\&S Fonds, series Cae, box I2, file io.

6o Irving Layton to Claire Pratt, 6 January 1964, M\&S Fonds, series Cae, box II, file 2I. 
verse left Layton "overjoyed" $6 \mathrm{r}$ and he looked forward once again to working closely with his trusted editor.

Before he had received Pratt's positive response, Layton had already begun to send her additional poems for inclusion in the manuscript. He continued to offer replacement poems and, at the final hour, tried to sneak in several poems through Ruth Taylor, Jack McClelland's executive assistant. Pratt's rebuke belied her affection for a poet who clearly tried her patience: "You promised me you would not send any more poems so now I have proof that you are not a man of honour. No wonder you slunk the poems in behind Ruth! Irving, there is no room in the book for any more poems." ${ }^{62}$ Layton mustered his playful side - the most appealing aspect of his personality - to subdue Pratt: "Honestly I didn't mean to go behind your back. I was having some correspondence with Mrs. Taylor and I thought I'd include the poems in one letter I'd written her. Of course I knew she'd show them to you. Knowing the faint-hearted person you are I might have hoped that in showing them to you Ruth would add her plea to mine." ${ }^{63}$ It was, in fact, his spirited nature that most drew Pratt to Layton and she forgave all his foibles - but stood her professional ground and refused to insert the late poems.

While she coaxed Layton to pen yet one more bombastic preface for the forthcoming volume, she sought the intervention of Jack McClelland on a separate matter. Pratt was troubled by Layton's poem "In Praise of Eros," which invoked the conflict between John F. Kennedy and Nikita Khrushchev during the Cuban Missile Crisis of October 1962. She believed many readers - the November 1963 assassination of Kennedy was still a fresh memory - would find the poem offensive and sought to exclude it from the collection. In light of her failed attempt to convince Layton to remove "Why I Don't Make Love to the First Lady" from The Swinging Flesh, Pratt asked McClelland to take on this new battle. He warned her that "the last time I had a confrontation [with Layton], I lost, too," but he hoped to succeed in this instance. Pratt was correct to enlist McClelland, for he convinced Layton of the risk associated with publishing the poem: "there is no one at this end that feels that this will give us anything

6I Irving Layton to Claire Pratt, I5 January I96[4], M\&S Fonds, series Cae, box II, file $2 \mathrm{I}$.

62 Claire Pratt to Irving Layton, 2I May 1964, M\&S Fonds, series Cae, box II, file 2I.

63 Irving Layton to Claire Pratt, 23 May 1964, M\&S Fonds, series Cae, box II, file $2 \mathrm{I}$. 
but serious trouble. Again let me emphasize that this has nothing to do with the poem. It's clever and witty, but migod, please!"84 McClelland's powerful argument held sway. For all his zeal, Layton sought to avoid "serious trouble" in the form of legal censure and agreed to the removal of the poem.

Layton solicited Pratt's editorial help with the preface and the arrangement of poems in the volume. Her guiding, conciliatory way suited the poet, who was not naturally compliant. As we have seen, however, Pratt was neither selfless nor humourless in her devotion to Layton and his verse. As she prepared to send Layton the proofs of The Laughing Rooster - Newfeld's elegant and innovative design for the book incorporated woodcuts of a rooster - she asked, "Now that I have, at great pains, done everything you asked, where is my ode?"65 Layton's own comic reply could not conceal his gratitude: "Claire, my love ... Because you were so patient with my repeated requests, I've put you into my special roster as Saint Claire and I pray to you each night before going to bed. I shall write a poem this summer and title it SAINT CLAIRE."66

Regrettably, neither Layton's ode nor his response to the news that chronic ill health finally forced Pratt's resignation in April I965 is available, but there can be no doubt that her departure from McClelland and Stewart left a profound mark on the poet who felt closely allied to his gifted editor. Throughout their association, at once richly productive, deeply satisfying, and frequently trying, Layton expressed his care and admiration for Pratt, a faithful editor who elicited his best work and always warmed to the life force behind his imperious exterior.

Physically, Pratt could no longer meet the day-to-day demands of publishing, but she retained her interest in books and authors and continued her editorial work on a freelance basis. She worked with Norah Story and William Toye on The Oxford Companion to Canadian History and Literature, issued by Oxford University Press Canada in 1967. In 1968, she began work on a Canadian style manual for McClelland and Stewart. Press Porcépic was among her other clients. She also pursued her own writing projects and was awarded

${ }^{64}$ Jack McClelland to Irving Layton, I7 January 1964, M\&S Fonds, series Cae, box II, file 2I.

65 Claire Pratt to Irving Layton, 9 June 1964, M\&S Fonds, series Cae, box II, file $2 \mathrm{I}$.

66 Irving Layton to Claire Pratt, I4 June 1964, M\&S Fonds, series Cae, box II, file 2I. 
a Canada Council grant in support of a genealogical study of her father's forebears. In I970, Jack McClelland was not surprised to receive a polished, elegantly written manuscript that showcased Pratt's professionalism. The following year, he published The Silent Ancestors, in large part to honour Pratt's "great contribution to McClelland and Stewart." 67

Pratt may have resigned from McClelland and Stewart - her departure left a major gap in the firm's editorial department - but she never truly retired. From 1965 onward, she devoted more time and energy to painting. Critic Robert C. Brandeis offers a detailed and compelling portrait of Pratt the artist in his 2000 articles, "Claire Pratt: Art and Adversity" and "The Graphic Work of Claire Pratt." 68 She also loved to travel and often was accompanied by her mother on trips to Newfoundland and overseas.

In 1970, Jack McClelland recognized Pratt as "the best book editor in the country." ${ }^{69}$ One of a line of influential editors in a new field that was emerging in Canada in the 1950s, Pratt's success was the result of a rare combination of charm, resolve, and intelligence - she once claimed "I am being taught my own work" standard for editors, female and male alike, who would follow her lead. In 1969, three years after Pratt's departure, Linda McKnight and Anna Szigethy (later Anna Porter) joined McClelland and Stewart, McKnight as editor and Szigethy as editorial co-ordinator. McKnight eventually rose to the position of president and publisher of the firm, and Porter became president of McClelland and Stewart-Bantam Limited before resigning to establish her own publishing company, Key Porter Books. Editor Douglas Gibson worked at Doubleday Canada and the Macmillan Company of Canada before joining McClelland and Stewart in 1986 to launch his own prestige imprint, Douglas Gibson Books.

Claire Pratt entered the book trade just as Canadian writers and writing were on the rise and her considerable editorial efforts helped foster the literary momentum that drove McClelland and Stewart. In turn, Jack McClelland gave her the opportunity to professionalize the

67 Jack McClelland to Anna Szigethy, 7 October 1970, M\&S Fonds, series C, box 2, file Pratt: Transmittals.

68 See Brandeis, "Claire Pratt" and "The Graphic Work of Claire Pratt," $D A$ : A Journal of the Printing Arts 46 (Spring-Summer 2000): 29-33.

69 Jack McClelland to Claire Pratt, I4 September 1970, M\&S Fonds, series C, box 2, file Pratt: Transmittals.

70 Quoted in Brandeis, "Claire Pratt," I5. 
role of editor and she did so with grace and aplomb. McClelland's early confidence in Pratt was sound, for she was an especially talented editor and a landmark figure in Canadian publishing.

\section{SOMMAIRE}

L'objet de cet article est l'analyse des neuf années de service (19561965) durant lesquelles Claire Pratt, une figure de proue de l'édition canadienne, fut l'éditrice principale à McClelland and Stewart, apportant ainsi une contribution des plus significatives à la littérature canadienne. Mme Pratt, en tant qu'assistante de Jack McClelland, le patron charismatique de la firme, mena à bien les défis associés à l'édition littéraire canadienne tout en récoltant les succès.

Elle travailla également en étroite collaboration avec Malcolm Ross, un professeur d'anglais, qui agit à titre d'éditeur de la collection de livres de poche de la firme appelée New Canadian Library. Elle édita plusieurs œuvres de célèbres écrivains du Canada, dont le parlementaire Stanley Knowles, le journaliste Peter C. Newman, l'historien W.L. Morton, les romanciers Henry Kreisel et Margaret Laurence et le poète Irving Layton. Mme Pratt entreprit sa carrière dans le commerce du livre au moment où les écrivains canadiens et l'écriture en général obtenaient de plus en plus la faveur du grand public. Elle consacra tous ses efforts en vue de suivre la ligne de conduite en vigueur chez McClelland and Stewart. En retour, Jack McClelland lui laissa toute la latitude requise pour l'exercice de son métier d'éditrice, qu'elle pratiqua d'ailleurs avec brio et aplomb. 
